\title{
Latest developments in career counselling in South Africa: towards a positive approach
}

\author{
Jacobus G Maree
}

\begin{abstract}
Fundamental changes in the workplace across all countries in recent times call for a contemporary response from career counselling theorists and practitioners as well as researchers and clients. An approach is needed that will enable career counsellors to equip clients with the necessary skills to respond to these changes - a positive career counselling approach. The article focuses briefly on global developments in the field and, more particularly, on the role of different economic waves in these developments. It then discusses the main theoretical approaches that have guided the career counselling profession over the past 120 years. It is argued that 20 th-century approaches to career counselling no longer adequately serve the needs of $2 \mathrm{I}$ st century and that a combined quantitative+qualitative approach may be the answer. Next, career construction principles and life designing are discussed - the first-ever 'true' career counselling theory - and an explanation of the need for a new approach in South Africa is provided. The article then goes into the contextual influences on career counselling in South Africa and the challenges facing institutions of education and training in this regard. It ends by proposing how career counsellors can exploit change to advance positive career counselling - the ultimate aim of theory and praxis in the field.
\end{abstract}

\section{Keywords}

Career construction, career counselling, counselling waves, economic waves, life designing, postmodern, qualitative assessment, quantitative assessment

Counselling theories provide counsellors with the theoretical foundation to establish 'best practice' in the best interests of clients. In the 21 st century, best practice involves instilling in people the ability to think critically, deal with challenges creatively, construct and advise themselves, and make sound decisions. Also, a proper understanding of career counselling in South Africa first requires an understanding of global developments in the field.

University of Pretoria, South Africa

Corresponding author:

Jacobus G Maree, Faculty of Education, University of Pretoria, Pretoria 0002, South Africa.

Email: kobus.maree@up.ac.za 


\section{Ever-changing world of work}

Much has been written about the dramatic changes that have taken place in the world of work in recent decades and their impact on the career lives of workers (Sharf, 2010). Societies in transition no longer provide people with the social, organizational, and moral frames of reference that were provided in earlier times (Guichard, in press). A dynamic response to work-related developments and challenges is required by 21 st-century people.

Shifts in the world of work (the result of succeeding economic waves, the fourth wave in particular) pose challenging questions to career counsellors and clients alike. Many employers can no longer 'guarantee' lifelong employment and regular promotion, and employees accordingly no longer feel obliged to remain loyal to one organization throughout their lives. Shortterm contracts rather than lifetime employment are, as forecast by Handy (1995) and Hughes (1997), commonplace today. Modern companies tend to specify the specific skills and capabilities they are looking for in prospective employees rather than advertise specific jobs ('dejobbing'; Aswathappa, 2005). This takes place against the backdrop of organizational fluidity where companies offer employees fewer and fewer guarantees. Because of the ongoing changes and uncertainty in the 21 st-century work-world, writers on the subject have to devise new terms to describe the latest developments in the field and innovative ways of meeting the challenges and moving forward.

The following terms are often used to describe the 21 st-century work situation: 'customized' (less willing to sacrifice personal time in the interest of their careers, people modify or tailor their career portfolios according to their own needs as well as the needs of specific organizations; moving up the corporate ladder is less important than taking care of one's personal needs) (Benko \& Weisberg, 2007), 'kaleidoscopic' (a career created on one's own terms and defined by one's own values, choices, and parameters) (Mainiero \& Sullivan, 2005), 'postindustrial' (people no longer have 'stable' work identities; instead, they are expected to redefine themselves continually in work contexts) (Gershuny, 1993), 'boundaryless' (a move towards independence of traditional agreements with organizations) (Arthur, 1994; Arthur \& Rousseau, 1996), 'portfolio' (people contract their skills in various contexts but also self-employed agreements) (Handy, 1995), and 'protean' (people's ability to remain resilient and deal with the effect of new technologies and new concepts of work) (Baruch, 2004; Hall, 1996).

Portfolio and protean careers in particular refer to people who contract out their skills in various contexts and indicate a preference for self-employment (Fenwick, 2004). Personal values and reliance on themselves rather than on employers are increasingly guiding people in their search for career and life success. Verbruggen, Dries, and Van Vianen (2013) believe that career counselling should be made available to all people irrespective of their age and the stage in their working lives. They add that career counselling should be broadened to include not only help with important career-related decisions but also help with the (self-)management of people's careers, including dealing with change and uncertainty.

Workers today are feeling alienated and isolated by the changes and uncertainties in the labour field, and we, as psychologists in the first and career counsellors in the second place, need the theoretical and practical skills and know-how to help our clients harness these changes and uncertainties to their own advantage. Hartung (2013) states that the links between people's work and their mental health have become more perceptible: 'Individuals confront career planning, work entry, job search, job loss, work inopportunity, work stress, and work adjustment in an era of severe economic downturn and "dejobbing" where assignments replace jobs'. People are expected to become more adaptable, to reflect on their situation constantly and to acquire the skill to regulate and 
manage themselves in the absence of stable organizational structures that served as holding environments in the past. They have to become holding environments for themselves and for others.

Changes in the world of work have inevitably impacted career counselling theory and practice (Savickas et al., 2009), obliging theorists and practitioners alike to formulate timely and adaptive responses to these changes.

\section{Waves in the economy: focus on the third and fourth waves}

The economic situation at any given time influences developments in the field of career counselling. The historical evolution of career counselling can best be understood by tracing its link with the different global economic waves. During the first (agricultural) economic wave (roughly 18501910), workers used the land to make a living, and in the second (industrial) economic wave (roughly 1900-1950), the focus was on 'mass fabrication of fabricated goods' (Molitor, 2000, p. 324). 'Jobs' (a new concept) were created (Savickas, 2007).

In the course of the third (service) economic wave (roughly 1940-1990), the skills of third-party providers were used to render specialized services. A career was considered as the pursuit of a particular occupation during a worker's working life marked by a gradual climb up the career ladder involving ever-increasing complexity levels and responsibilities (Savickas, 2000). The fourth (information communication technology) economic wave (1994-) was facilitated by communication and computer technology (Hartung, 2011; Savickas, 2011a). The workplace and work content and work values are changing. Vastly differing perceptions exist about work, and the meanings that people attach to the workplace are changing rapidly. The notion of 'climbing up the ladder' of seniority in the workplace is rapidly disappearing (Bimrose, 2010). An obvious next step would be for career counsellors to attempt to predict future economic waves and formulate appropriate positive responses timeously.

\section{Epistemological approaches that have underpinned and guided career counselling over the past I 20 years}

\section{Traditional approach}

Savickas (2011b) argues that the demise of jobs in the 21 st century has led to new questions posed by vocational psychologists and career counsellors:

The employment premise of matching individuals to jobs is fading as the digital revolution produces jobless work. In response to the recurring transitions that they will face as they move from project to project, individuals cannot maintain their employment, so they must maintain their employability. (p. 6)

In the predictable work environments of the past, the person-environment matching or fit paradigm (finding an optimal 'fit' between work seekers and possible jobs) and the notion of preparing people for stable career paths served a useful purpose. Today, however, people are expected to construct and advise themselves with the help of career counsellors. Following a 'test-and-tell' approach or finding an optimal 'fit' between people and their work environment (based on trait and factor theory) in isolation no longer suffices. Hartung (2011) states that the realization has gradually grown that 'objective' (psychometric) tests often fail to adequately assess subjective or phenomenological career counselling experiences and variables. In addition, people change over time as often do their interest profiles resulting in unreliable profiles (Hartung, 2011; Nauta, 2010; 
Savickas et al., 2009). Basing career choices on such profiles can lead to career disappointment in younger as well as older people (Borchard, 1995).

\section{Postmodern approaches}

Postmodernism (a collection of theories and approaches with similar features) stems from the view that 'reality' is created by entities that differ in terms of personal, historical, and cultural contexts (Hergenhahn, 2005). The incorporation of not only the objective but also the subjective meanings people attach to their career and life stories is central to successful career choices and life designing. Career counsellors who follow a postmodern (an umbrella term for qualitative, narrative, or storied perspectives) approach are as interested in interpreting the subjective aspects of career counselling (i.e., eliciting clients' career and life stories) as they are in interpreting clients' 'objective' test results. The value of qualitative approaches to career counselling has been increasingly recognized in recent years with the design, development, and implementation of narrative-based theories and assessment instruments and techniques in career counselling consequently receiving considerable attention.

\section{Merits of a combined, qualitative +quantitative approach to career counselling}

The extent of the changes in the world of work described earlier inevitably led to a major paradigm shift (cf. Kuhn, 1996) in career counselling theory and practice culminating in a combined qualitative+quantitative approach.

Duffy and Dik (2009) argue that quantitative approaches used in isolation ignore clients' distinctiveness and that steps should be taken to ensure greater reliability and trustworthiness in career counselling assessment. Triangulating and crystallizing assessment results, as a means of ensuring greater reliability, can best be achieved by using a combination of quantitative and qualitative assessment techniques while at the same time assessing clients on different occasions to determine whether their interest profiles remain consistent over time.

A quantitative approach combined with qualitative elements is gaining increasing acceptance. It is seen as a means of empowering career counsellors to help clients find meaning in their lives, accept authorship of their careers and life stories (and their actions), and become more adaptable, employable, lifelong learners. Qualitative techniques together with quantitative techniques demonstrate how contemporary theories and goals in career counselling can be merged to provide a viable framework for the interpretation, explanation, and directing of career-related behaviour. Such a combined approach equips career counsellors with the skills to assist individuals construct meaningful careers, design successful lives, and make social contributions through work (Savickas, 2011b).

\section{Concerns about a new approach to career counselling}

Notwithstanding what has been said in the preceding paragraphs, some people still reject the qualitative paradigm and/or the paradigm shift from a traditional approach to a combined approach to career counselling. They believe that it has not been 'proven' that a changed approach to career counselling is needed (i.e., there is insufficient empirical justification for using qualitative approaches) and that there are also insufficient data to suggest that narrative approaches facilitate 'better' counselling outcomes than 'positivist' approaches.

'Abandoning' an approach that has served practitioners well over time does not make sense to some theorists and practitioners; however, there is no doubt that we should endeavour to use the best elements in both approaches (quantitative and qualitative). 


\section{Career construction principles and practices}

\section{Narrative counselling}

Career counselling theorists and practitioners are increasingly employing narrative methods to help people achieve the inner stability they need to navigate the world of work in the 21 st century (Hartung, 2013). This implies reflexive construction, deconstruction, co-construction (collaboration between client and counsellor), and reconstruction (Savickas, 2011a). The belief that people are the main actors (McAdams \& Olson, 2010) in their career and life stories lies at the heart of the narrative approach to career counselling. Clients' multiple micro- and macro-career stories therefore need to be elicited and built on during the counselling process to facilitate sound career-related decisions. Clients' life plots are uncovered and shaped during this process (Cochran, 2011; Savickas, 2011a). The narrative approach can be likened to a (psycho)drama where the actors act out their lives (Sharf, 2010). Personal agency is achieved by clients in that they are active agents in their development while, at the same time, their emotions and passions are highlighted (Savickas, 2011a).

Career counsellors join clients in their journey and help them face the unique challenges inherent in choosing appropriate careers and in scripting career and life stories for themselves (Cochran, 2011). The scripting process is well suited to exploring personal meanings, dealing with repeated crossroads, and finding meaning in life.

The narrative approach is closely aligned with career construction theory.

\section{Career construction theory}

In terms of career construction theory, developed from the interpretive research and praxis paradigm described by Savickas (2005) and Hartung (2011), clients and counsellors co-construct and co- and/or re-author clients' stories in a way that turns intention into movement forward and painful themes into hope and, ultimately, enables clients to realize the importance of making social contributions.

Career counselling is thus regarded as an interactive, co-constructive process between counsellor and client whose relationship is characterized by compassion, truthfulness, and mutual respect (Maree, 2013; Savickas, 2011a). Career construction theory (Hartung, 2013; Savickas, 2011b) is underpinned by the concept of career as story (career-life story) and is closely associated with the vocational psychology model of vocational development.

Career construction is, in essence, co-construction of career-life stories. Career counsellors use the cultural resources that clients bring to consulting rooms to co-construct action plans and help clients move forward. The numerous bits of information provided by clients are regarded as meaningful micro-stories that can be woven into grand, comprehensive stories (Hartung, 2011; Savickas, 2011a). All the different systems, subsystems, and contexts that have shaped and continue to shape clients' career and life stories require close consideration.

Facilitation of career adaptability is a major element in career construction theory.

\section{Career adaptability concepts}

Savickas (2013) and Hartung (P. J. Hartung, personal communication, 23 October 2012) believe that prevailing career theories neither satisfactorily explain the uncertain and fast-changing career structure in the 21 st century nor speak to the needs of marginal and exterior workers. These authors argue that the social constructionism paradigm (the view that reality is the product of relationships, as 
opposed to constructivism, which views reality as the product of interpretation by the individual) opens up new constructs for examining and managing 21 st-century work lives. Career counsellors are today attempting to emphasize identity rather than personality, adaptability rather than maturity, stories rather than scores, and action rather than intention in their efforts to help people navigate transitions over the course of their lifetimes. Career counselling aims primarily at facilitating career adaptability and instilling adaptive behaviour in people and is consequently defined as an intervention focused on 'the daily life adjustment issues faced by reasonably well-adjusted people, particularly as they cope with career transition and personal development' (Savickas, 2007, p. 183).

Career adaptability, the origin of particular attitudes, beliefs, and competencies, involves the developmental tasks, role transitions, and coping strategies used by individuals to navigate transitions and changes (Hartung, 2011). Each adaptability operation bolsters the group and enhances individuals' ability to adapt. The four dimensions of career adaptability (concern, control, curiosity, and confidence), each referring to a specific developmental task, represent the general adaptability resources and strategies used by individuals to cope with critical tasks, transitions, and traumas during the construction of a career (Hartung, 2011; Savickas, 2005).

\section{Reflection and reflexivity as integral aspects of 2 Ist-century career counselling}

Clients are enabled to reflect on their career and life stories and subsequently to reflect on these reflections. Reflection on reflection is aimed at supporting self-construction or self-realization (Maslow, 1987). In the process, motivation and intention are transformed into action (Savickas, 2011a) as motivation on its own means little (Krieshok, Black, \& Mckay, 2009). The multi-method approach (quantitative+qualitative; data are collected and analyzed concurrently and converged (Creswell \& Plano Clark, 2007)) referred to previously incorporates objective as well as subjective methods and strategies (Hartung, 2011; Maree, 2013) to identify inherent strengths and motives (major life themes) in clients.

\section{Life designing: essence of the first-ever career counselling theory}

Career counsellors have various career services are at their disposal. Savickas (2011a) states that clients' idiosyncratic needs determine which particular career service practitioners should apply, namely, vocational guidance to identify occupational fit, career education to foster vocational development, or career counselling to design a work life: 'Each career intervention - whether it be guidance, education, or counselling - is valuable and effective for its intended purpose' (Savickas, 2011a, p. 8).

Life design counselling is a term used for the new coordinated counselling theory. The life design counselling paradigm is the first-ever coordinated counselling theory: Super (1990) and Holland (1997) previously espoused only theories of vocational behaviour and development, not theories of career counselling (M. L. Savickas, personal communication, 13 March 2013). The life design framework for career counselling is structured to be lifelong, holistic, and contextual and to make provision for adequate self-construction. It operationalizes and extends Guichard's (2005) theory of self-constructing and Savickas' (2005) theory of career construction (both of which describe occupational behaviour and its development). Ultimately, the Savickian contribution comes down to enabling people to author their career and life stories and design successful lives and make social contributions. This is why the life design counselling model has liberated career counselling from the many restraints imposed on it by an excessively positivist approach (Maree, 2013), an approach that left insufficient room for consideration of issues such as subjectivity, personal growth, discovery, and improving the sense of self during career construction. 
Life design intervention emphasizes action steps rather than test scores and profile interpretations. Life designing has six general steps (Duarte, 2010; Savickas et al., 2009). First, the aim of the intervention needs to be co-defined by counsellor and client through a working alliance. Second, clients are guided towards exploring their system of subjective identity shapes; in other words, how they see and organize themselves. Clients are requested to reflect on and shape their stories by articulating their experiences, actions, interactions, interpersonal relationships, and future anticipations. Third, ways in which clients' perspectives can be broadened are considered when clients narrate their stories and, in doing so, make the stories more objective and understandable. By objectifying their stories, clients can study them from a distance so that they can be reorganized, revised, and revitalized. Following the revision of their stories, clients place their problems and challenges in the revised stories (fourth step) after which they begin to identify with a 'new' role and identity. In the second last (fifth) step, clients are encouraged to identify activities they can participate in to actualize their new, possible identities. An action plan (Tiedeman, 1964) is then drawn up and executed. The last (sixth) step comprises short- and long-term follow-ups.

\section{Updating counselling theories and practices: a South African perspective}

As is also the case elsewhere in the world, millions of South Africans have not had the opportunity to construct themselves to design successful lives, to make social contributions, and to achieve self-completion (find deeper meaning in their lives). Bar-On (2007) sums this up as follows:

Conditions in which people are deprived of an opportunity to blossom hide, if not bury, many gifted individuals, compounding the human tragedy that they evoke ... Have we lost another Abraham, Jesus, Nostradamus, Spinoza, Mahler, Kafka, Pissarro, Marx, Freud or Einstein who may have significantly contributed to human existence and mankind? (p. 137)

One could add Nelson Mandela, Desmond Tutu, F. W. de Klerk, Mother Teresa, and many others to that list.

Bar-On, however, also believes the world has the human capital and resources to bring about change. The author has met many unacknowledged people who have contributed markedly to career counselling in the most challenging circumstances - people who are actively contributing to the design of a positive career counselling strategy that can be applied successfully across the diversity continuum irrespective of a person's gender, socio-economic circumstances, sexual preference, colour, race, age, creed, or geographical location.

All South Africans should be actively engaged in constructing themselves and in accepting ownership and responsibility for (re-)authoring their lives. The focus should be on individuals and their personal stories rather than on how individuals differ. Ways have to be found to enable all South Africans to share in the benefits of a combined qualitative+quantitative theoretical framework in career counselling. Advancing career counselling in group contexts is critical. African society, for example, with its strong focus on the group, storytelling, and Ubuntu (de facto natural resources in African contexts), is ideally suited to a narrative approach.

Such an approach can facilitate understanding of individual and collective strengths and weaknesses in personal and career stories, help people from all walks of life exploit strengths and navigate weaknesses, enhance assessment and improve employment opportunities, help people deal with major life transitions, assist people to take their rightful place in society, and link career and life stories with life's fundamental choices (Savickas, 2005). 
The career counselling theory base in South Africa needs to be more inclusive, holistic, context based, and suitable for individuals as well as small and large groups of people. The development of indigenous models, methods, and materials should therefore be promoted without losing sight of the importance of international collaboration (Savickas, 2011b).

\section{Contextual influences on theory development in career counselling in South Africa}

Maree and Van der Westhuizen (2011) maintain that neither the particular values in accordance with which nor the climate in which most counselling theories developed elsewhere can be transposed directly to the South African situation. However, this is what actually happened until very recently. Career counselling theories formulated elsewhere in the world have usually been accepted in South Africa and applied to all South Africans uncritically. Consequently, career counselling in South Africa is driven largely by individual needs and not by the needs of the group, which is the focus in African culture. South Africa is also officially recognized as one of the most unequal societies in the world (with the highest Gini or inequality index) (Statistics South Africa [Stats SA], 2008). Small sections of the population are extremely wealthy while large sections live in dire poverty. The situation is exacerbated by inadequate throughput rates in higher education, growing unemployment and rising crime levels. Inadequate achievement in South African higher education is a source of major concern: Whereas only about $25 \%$ of students at residential universities graduate within the minimum time allowed, only $35 \%$ of all students enrolling during any given year obtain their degrees within five years. Roughly $55 \%$ of them will never graduate. The situation is exacerbated by the fact that about $50 \%$ more white than black students graduate. In fact, less that $5 \%$ of African and coloured students succeed in graduating (Ndebele, 2012, p.15).

\section{South African institutions of education and training}

Primary, secondary, and tertiary education and training institutions have a key role to play in making South Africa locally self-sufficient and globally competitive. Ways must therefore be found to counter the high dropout rate at secondary and tertiary institutions of learning. For example, career counselling in one-on-one settings should be augmented by counselling in workshop (group) format, in paper-based communication format, and, ultimately, in electronic format. The South African Qualifications Authority (SAQA) helpline is an example of how this can be achieved.

Schools. Career counselling in South African schools was for many years compromised by apartheid ideology, a lack of teacher training in school guidance and counselling, under-resourced schools, and the low-status-accorded career counselling. Kay and Fretwell (2003) and Leach, Akhurst, and Basson (2003) contend that the makeshift implementation of guidance and counselling in disadvantaged schools has led to career indecision and subsequent disillusionment among many university entrants.

To make matters worse, in 1995, the National Education Department placed a moratorium on the use of psychological tests in schools (especially in group format). Learners from more affluent families attend well-resourced schools that have overcome the moratorium by soliciting the services of private psychologists to assess large groups of learners. However, most learners, who are from low socio-economic backgrounds, attend poorly resourced schools and have virtually no access to modern, up-to-date assessment (especially assessment aimed at career counselling). 
Responsibility for test use in schools in South Africa rests mainly with school support services that operate from district offices with limited capacity.

The increased emphasis on life orientation as a means of facilitating life skills acquisition in South African schools has been generally welcomed as it helps people in all age groups choose appropriate careers and design successful lives. A clear overlap exists between the concepts life orientation, life skills, and life designing (all relating to ways in which people can be guided to construct themselves and attain an adequate sense of self and a stable career identity). Attention needs to be given to the recruitment and training of dedicated life orientation teachers.

A rethink is required on how career counselling is promoted at schools and whether the theory and practice of life orientation and life skills acquisition is appropriate and satisfactorily aligned with South African and global developments. At this stage, the answer seems to be a resounding 'no' (Van der Vyver \& Oswald, 2005), thus highlighting the need to ensure that career counselling theory is sound and its outcomes are clearly stipulated and easily measurable. This is particularly important in the case of the most remote and poorest regions, informal settlements, and townships.

Tertiary training institutions. All tertiary training institutions currently offer a range of (career) counselling and academic support services to students and prospective students (Kay \& Fretwell, 2003). However, at many institutions, there seems often to be a lack of physical and human resources as well as indifference to counselling services on the part of students (Chireshe, 2012). Developing and implementing more relevant counselling theories and practices and positioning counselling in contexts more suited to the needs of all South Africans are required. Career counselling interventions should be based on three broad principles:

(a) Access (making counselling freely available to everyone with all career counsellors, ideally, being able to speak at least one indigenous language).

(b) Equity (no privileging of any specific group on any grounds).

(c) Redress (dealing with historical imbalances still prevalent in South Africa).

One way of achieving these principles would be to extend community service to, for example, teachers and educational psychologists, thereby expediting the presentation of life orientation (and career counselling in particular). Students across disciplines should also be exposed to the world of work from an early stage to promote smoother entrance into the workplace. Regular audits should be conducted to assess the viability of qualifications, and qualifications that do not lead to employability in some form or other should be adapted to suit present-day market needs. Furthermore, since no feature of career counselling is more important than helping people find work, tertiary training institutions should do much more to help graduates gain employment after their studies (only 30\% of university graduates today manage to secure employment) (Bloch, 2009; Blumenthal, 2009).

The Green Paper for post-school education and training (Department of Higher Education [DoHE], 2012) should be welcomed as it stresses the importance of collaboration at all levels (basic education and training, higher education and training, and the world of work) in extending career counselling. The green paper focuses on the needs of the most vulnerable members of society who often live in remote areas and have little access to education and training. The strategies proposed in the paper have the potential to bring about meaningful change in the lives of hundreds of thousands of people, particularly prospective students and the unemployed. The paper calls for 'the establishment of [a South African] educational [system] where every teacher is trained as a counsellor capable of administering career counselling' (Nzimande, 2010). South Africans should also avoid engaging in the generally negative discourse about the challenges facing the country. 


\section{Developing new assessment instruments}

Very few psychometric tests have been designed for the diverse South African population as a whole. Cultural relevancy as part of the theoretical underpinning of these tests is also not always considered by psychologists with the result that they often fail to take into account the shortcomings of the tests when working cross-culturally. New assessment instruments and strategies need to be developed based on the approach spelt out in the preceding paragraphs. Shuttleworth-Jordan (1996) says that the issue of cross-cultural test use should be addressed over time at different levels and that attention should be given to the development of teacher-friendly assessment instruments for the enhancement of learning. Likewise, the idea of dynamic assessment should be developed further. South African psychologists, in particular, need to consider whether their assessmentrelated actions help prepare people for the radically different world of the 21 st century. These actions should, ideally, equip learners to become more self-sufficient, to learn and act more effectively, and to accept responsibility for their own learning process. Professionals should also continually evaluate the effectiveness of their own actions and methods. This can be done through tests by psychologists and teacher-friendly measuring instruments.

Test-development research should form part of a country's broader social and economic objectives (Oakland, 2004). An indigenous theory base and approach is needed in South Africa for the development of appropriate assessment instruments - an approach that can help people find meaning in their lives, accept responsibility for authoring their career and life stories, and become lifelong learners who can adapt to a multifaceted and unpredictable world of work.

The practicalities of the 21 st-century labour market should co-determine assessment strategies, and theory development should integrate benchmark concepts such as internationalization, globalization of the workforce, labour surplus, downsizing, outsourcing, corporate reorganization, diversification, lifelong learning, multi-skilling, and the acquisition of information communication technology skills (Maree, 2009). Intervention should aim at enhancing students' employability, improving their career adaptability, and helping them assume authorship of their career and life stories. Feedback should encourage them to become critical thinkers, creative problem solvers, and skilled decisionmakers, thereby increasing their employability rather than merely helping them find employment.

\section{Conclusion}

Changes in the world of work pose many questions to workers in the 21 st-century information age. A timely response by theorists and practitioners in career counselling is required if they are to remain relevant and useful to their clients. Global developments impact South African career counselling and need to be factored into local theory and practice. The local context should also be considered to ensure that the best interests of clients always take precedence over any other consideration.

The positive approach advocated by Mark Savickas to address the questions arising from workrelated changes in recent decades underlies most of the argument in this article. Briefly summarized, the ultimate aim of career construction and life designing is to equip career counsellors with the skills and strategy needed to help people fit careers into their lives rather than fit their lives into their work. Using Savickas' approach, career counsellors can overcome many of the weaknesses associated with traditional approaches to career counselling (Maree, 2013). The narrational approach advocated here facilitates reflexive social co-construction of meaning (Blustein, Palladino Schulteiss, \& Flum, 2004) and can help clients deal effectively with repeated transitions as and when they occur (Di Fabio, 2012; Duarte, 2010; Savickas et al., 2009). 
In summary, the approach advocated in this article can help resolve the many challenges associated with the theory and practice of career counselling in South Africa. The strategies discussed and proposed here may not be entirely new or the 'complete' answer. However, they may provide some guidance on how South Africans can choose suitable careers, design successful lives, and make social contributions. Hopefully this article will contribute to the advancement of constructionist perspectives and career construction generally and life designing in particular. Surrendering to the negativity implicit in some of the challenges posed by an evolving world is not the answer. We are only in 'dire straits' if we choose to be. A better course is an action-orientated, positive approach where we accept change as an opportunity to construct ourselves and others to move forward and ensure a positive future for future generations.

\section{Funding}

This research received no specific grant from any funding agency in the public, commercial, or not-for-profit sectors.

\section{References}

Arthur, M. B. (1994). The boundaryless career: A new perspective for organizational inquiry. Journal of Organizational Behavior, 15, 295-306. doi:10.1002/job.4030150402

Arthur, M. B., \& Rousseau, D. M. (1996). The boundaryless career: A new employment principle for a new organizational era. New York, NY: Oxford University Press.

Aswathappa, K. (2005). Human resource and personnel management. Delhi, India: Tata McGraw-Hill.

Bar-On, R. (2007). The relationship between emotional intelligence and giftedness. Gifted Education International, 23, 136-150.

Baruch, Y. (2004). Transforming careers: From linear to multidirectional career paths. Career Development International, 9, 58-73.

Benko, C., \& Weisberg, A. (2007). Mass career customization. Boston, MA: Harvard Business School Press.

Bimrose, J. (2010). Adapting in a changing world: Dealing with repeated career transitions. In K. Maree (Ed.), Career counselling: Methods that work (pp. 118-127). Cape Town, South Africa: Juta.

Bloch, B. (2009). The toxic mix: What's wrong with South Africa's schools and how to fix it. Cape Town, South Africa: Tafelberg.

Blumenthal, I. (2009). Seta head slams graduate-producing institutions. Durban, South Africa: East Coast Radio.

Blustein, D. L., Palladino Schulteiss, D. E., \& Flum, H. (2004). Toward a relational perspective of the psychology of careers and working: A social constructionist analysis. Journal of Vocational Behavior, 6, 423-440.

Borchard, D. C. (1995). Planning for career and life: Job surfing on the tidal waves of change. The Futurist, $29,8-12$.

Chireshe, R. (2012). Career guidance and counselling provisions at a South African university: Career advisors' reflections. The Anthropologist, 14, 305-310.

Cochran, L. (2011). The promise of narrative career counselling. In K. Maree (Ed.), Shaping the story: A guide to facilitating narrative counselling (pp. 7-19). Rotterdam, The Netherlands: Sense.

Creswell, J. W., \& Plano Clark, V. L. (2007). Designing and conducting mixed methods research. Thousand Oaks, CA: Sage.

Department of Higher Education (DoHE). (2012, February). Green paper for post-school education and training. Pretoria, South Africa: Author.

Di Fabio, A. (2012, July). Narratability and career construction: Empirical evidence of intervention effectiveness. State-of-the-Science Lecture: 30th International Congress of Psychology, Cape Town, South Africa.

Duarte, M. E. (2010, July). Restructuring career counseling: Objectives and instruments. 27th International Congress of Applied Psychology, Melbourne, Victoria, Australia. 
Duffy, R. D., \& Dik, B. J. (2009). Beyond the self: External influences in the career development process. The Career Development Quarterly, 58, 29-43.

Fenwick, T. J. (2004). Learning in portfolio work: Anchored innovation and mobile identities. Studies in Continuing Education, 26, 229-241.

Gershuny, J. (1993). Post-industrial career structures in Britain. In G. Esping-Andersen (Ed.), Changing classes (pp. 136-170). London, England: SAGE.

Guichard, J. (2005). Life-long self-construction. International Journal for Educational and Vocational Guidance, 5, 111-124.

Guichard, J. (in press). From vocational guidance and career counselling to life design dialogues. In J. Rossier \& L. Nauta (Eds.), Handbook of the life design paradigm: From practice to theory, from theory to practice. Hogrefe.

Hall, D. T. (1996). Protean careers of the 21st century. The Academy of Management Executive, 10, 8-16.

Handy, C. (1995). The age of unreason. London, England: Arrow books.

Hartung, P. J. (2011). Career construction: Principles and practice. In K. Maree (Ed.), Shaping the story: A guide to facilitating narrative career counselling (pp. 103-120). Pretoria, South Africa: Van Schaik.

Hartung, P. J. (2013). Using narratives in life-career design (ICAP Symposium Proposal: Counseling Psychology). Unpublished document.

Hergenhahn, B. R. (2005). An introduction to the history of psychology (5th ed.). Belmont, CA: Thomson Wadsworth.

Holland, J. L. (1997). Making vocational choices: A theory of vocational personalities and work environments (3rd ed.). Lutz, FL: Psychological Assessment Resources.

Hughes, P. (1997). Education and work: Dialogue between two worlds. Prospects, 27, 7-15.

Kay, L. E., \& Fretwell, D. H. (2003, April 15). Public policies and career development: A framework for the design of career information, guidance and counselling services in developing countries (Country Report on South Africa). Washington, DC: World Bank.

Krieshok, T. S., Black, M. D., \& McKay, R. A. (2009). Career decision making: The limits of rationality and the abundance of non-conscious processes. Journal of Vocational Behavior, 75, 275-290.

Kuhn, T. S. (1996). The structure of scientific revolutions (3rd ed.). Chicago, IL: The University of Chicago Press.

Leach, M. M., Akhurst, J., \& Basson, C. (2003). Counselling psychology in South Africa: Current political and professional challenges and future promise. The Counseling Psychologist, 31, 619-640.

Mainiero, L. A., \& Sullivan, S. E. (2005). Kaleidoscope careers: An alternative explanation for the opt-out revolution. The Academy of Management Executive, 19, 106-123.

Maree, J. G. (2009). Career counseling in the 21st century: South African institutions of higher education at the crossroads. South African Journal of Higher Education, 23, 429-435.

Maree, J. G. (2013). Counselling for career construction: Connecting life themes to construct life portraits: Turning pain into hope. Rotterdam, The Netherlands: Sense.

Maree, J. G., \& Van der Westhuizen, C. (2011). Profession of counseling in South Africa: A landscape under construction. Journal of Counseling and Development, 89, 105-112.

Maslow, A. H. (1987). Motivation and personality (2nd ed.). New York, NY: Addison-Wesley.

McAdams, D. P., \& Olson, B. D. (2010). Personality development: Continuity and change over the life course. Annual Review of Psychology, 61, 517-542.

Molitor, G. T. T. (2000). Emerging economic sectors in the third millennium: Introduction and overview of the 'big five'. Foresight, 2, 323-329.

Nauta, M. M. (2010). The development, evolution, and status of Holland's theory of vocational personalities: Reflections and future directions for counseling psychology. Journal of Counseling Psychology, 57, $11-22$.

Ndebele, N. (2013). A proposal for undergraduate curriculum reform in South Africa: The case for a flexible curriculum structure. Pretoria, South Africa: Council for Higher Education.

Nzimande, B. (2010). Teachers must be 'skilled counsellors'. Retrieved from http://www.news24.com/ SouthAfrica/News/Teachers-must-be-skilled-councillors-20100707 
Oakland, T. (2004). Use of educational and psychological tests internationally. Applied Psychology: An International Review, 53, 157-172.

Savickas, M. L. (2000). Renovating the psychology of careers for the twenty-first century. In A. Collin \& R. A. Young (Eds.), The future of career (pp. 53-68). Cambridge, MA: Cambridge University Press.

Savickas, M. L. (2005). The theory and practice of career construction. In S. Brown \& R. W. Lent (Eds.), Career development and counseling: Putting theory and research to work (pp. 42-70). New York, NY: John Wiley \& Sons.

Savickas, M. L. (2007). Internationalisation of counselling psychology: Constructing cross-national consensus and collaboration. Applied Psychology, 56, 182-188.

Savickas, M. L. (2011a). Career counseling. Washington, DC: American Psychological Association.

Savickas, M. L. (2011b). New questions for vocational psychology: Premises, paradigms, and practices. Journal of Career Assessment. Advance online publication. doi:10.1177/1069072710395532

Savickas, M. L. (2013). The theory and practice of career construction. In S. D. Brown \& R. W. Lent (Eds.), Career development and counseling: Putting theory and research to work (2nd ed., pp. 147-186). Hoboken, NJ: Wiley.

Savickas, M. L., Nota, L., Rossier, J., Dauwalder, J. P., Duarte, M. E., Guichard, J., . . Van Vianen, A. E. M. (2009). Life designing: A paradigm for career construction in the 21 st century. Journal of Vocational Behavior, 75, 239-250.

Sharf, R. S. (2010). Applying career development theory to counseling (5th ed.). Belmont, CA: Brooks/Cole.

Shuttleworth-Jordan, A. B. (1996). On not reinventing the wheel: A clinical perspective on culturally relevant test usage in South Africa. South African Journal of Psychology, 26, 96-102.

Statistics South Africa (Stats SA). (2008). Income and expenditure of households 2005/2006: Analysis of results. Pretoria, South Africa: Author.

Super, D. E. (1990). Career and life development. In D. Brown \& L. Brooks (Eds.), Career choice and development (2nd ed., pp. 192-234). San Francisco, CA: Jossey-Bass.

Tiedeman, D. V. (1964). The cultivation of career in vocational development through guidance-in-education (Harvard Studies in Career Development, No. 29). Cambridge, MA: Center for Research in Careers, Harvard University Graduate School of Education.

Van der Vyver, M., \& Oswald, M. (2011, October). Exploring systemic influences on initial decision making. Paper read at IAEVG Conference, Cape Town, South Africa.

Verbruggen, A., Dries, N., \& Van Vianen, A. (2013). The counseling needs of employed adults: Implication for career counseling. In A. Di Fabio \& J. G. Maree (Eds.), Psychology of career counselling (pp. 101116). Hauppauge, NY: Nova Science. 